\title{
EFEK MODEL PEMBELAJARAN BERBASIS MASALAH TERHADAP HASIL BELAJAR SISWA PADA MATERI LISTRIK DINAMIS DI KELAS X SEMESTER II SMA NEGERI 1 HINAI KABUPATEN LANGKAT T.A. 2013/2014
}

\author{
Rajo Hasim Lubis dan Sahyar \\ Jurusan Fisika FMIPA Universitas Negeri Medan \\ rajo.hasim@gmail.com
}

\begin{abstract}
ABSTRAK
Penelitian ini bertujuan untuk mengetahui apakah hasil belajar dengan menggunakan model pembelajaran berbasis masalah lebih baik daripada pembelajaran konvensional pada materi Listrik Dinamis di kelas $\mathrm{X}$ Semester II di SMAN 1 Hinai Kabupaten Langkat T.A. 2013/2014.Jenis penelitian ini adalah quasi experiment. Populasi dalam penelitian ini adalah seluruh siswa kelas X Semester ganjil SMAN 1 Hinai yang terdiri dari empat kelas. Sampel penelitian ini diambil dua kelas yaitu kelas $\mathrm{X}^{-}$ 1(sebagai kelas eksperimen) dan kelas X-2 (sebagai kelas kontrol) yang masing-masing berjumlah 30 siswa yang ditentukan dengan teknikcluster random sampling.Kemudian diberikan perlakuan yang berbeda, kelas eksperimen dengan model pembelajaran berbasis masalah dan kelas kontrol dengan pembelajaran konvensional.Data yang digunakan dalam penelitian inites essay,jumlah soal8 item yang telah divalidkan oleh validator. Dari hasil penelitian diperoleh nilai rata-rata pretes kelas eksperimen adalah 14,83 dan kelas kontrol adalah 16,17 sedangkan nilai rata-rata postes kelas eksperimen 67,5 dan kelas kontrol 58,67. Melalui uji t diperoleh hasil secara signifikan bahwa hasil belajar menggunakan model pembelajaran berbasis masalah lebih baik dibandingkan kelas kontrol yang menggunakan pembelajaran konvensional.
\end{abstract}

Kata Kunci: quasi eksperimen, pembelajaran berbasis masalah, konvensional

\section{PENDAHULUAN}

Pendidikan adalah proses pembentukan kecakapan-kecakapan fundamental secara intelektual dan emosional manusia. Oleh karena itu, pendidikan merupakan sarana terpenting untuk mewujudkan kemajuan bangsa dan negara. Pendidikan yang bermutu, akan tercipta sumber daya manusia yang berkualitas, akan tetapi salah satu persoalan besar yang dihadapi bangsa Indonesia saat ini adalah rendahnya kualitas pendidikan nasional.Rendahnya kualitas pendidikan tersebut disebabkan oleh banyak factor (Hasbullah,1991).

Berdasarkan data Education For All Global MonitoringReport 2012 yang dikeluarkan oleh UNESCO setiap tahunnya, pendidikan Indonesia berada di 
peringkat ke-64 untuk pendidikan di seluruh dunia dari 120 negara. Data Education Development Index (EDI) Indonesia, pada 2011 Indonesia berada di peringkat ke-69 dari 127 negara.

Masalah utama dalam pembelajaran pada pendidikan formal (sekolah) dewasa ini adalah masih rendahnya daya serap peserta didik. Hal ini tampak dari rerata hasil belajar peserta didik yang senantiasa masih sangat memperihatinkan. Prestasi ini tentunya merupakan hasil kondisi pembelajaran yang masih bersifat konvensional dan tidak menyentuh ranah dimensi peserta didik itu sendiri, yaitu bagaimana sebenarnya belajar itu. Dalam arti yang lebih substansial, bahwa proses pembelajaran hingga dewasa ini masih memberikan dominasi guru dan tidak memberikan akses bagi anak didik untuk berkembang secara mandiri melalui penemuan dalam proses berpikirnya (Trianto,2009).

Berdasarkan dari observasi awal peneliti pada saat PPLT (Program Pelatihan Lapangan Terpadu) di sekolah SMA Negeri 1 Hinai Kabupaten Langkat, tampak bahwa pembelajaran yang digunakan dikelas masih cenderung berpusat pada guru (teacher centered), sehingga siswa menjadi pasif dan belum pernah menggunakan model pembelajaran berbasis masalah. Permasalahan tersebut menyebabkan hasil belajar siswa kelas masih tergolong rendah. Selain itu jika dilihat nilai ujian fisika yang dicapai siswa rata- rata 55, masih jauh dibawah Kriteria Ketuntasan Minimum (KKM) yakni
75. Oleh karena itu, dalam hal ini diperlukan salah satu upaya untuk mengatasi permasalahan di atas yakni dengan mengembangkanmodel pembelajaran yang efektif,yang dapat menarik perhatian siswa, membangkitkan motivasi siswa, melibatkan siswa secara aktif, dan memperhatikan kemampuan siswa.

Adapun model pembelajaran yang akan diterapkan penelitiyaitu model pembelajaran berbasis masalah, karena pembelajaran berbasis masalah tidak dirancang untuk membantu guru menyampaikan informasi dengan jumlah besar kepada siswa. Akan tetapi pembelajaran berbasis masalah dirancang untuk membantu siswa mengembangkan keterampilan berpikir,keterampilan menyelesaikan masalah, dan keterampilan intelektualnya, mempelajarai peran-peran orang dewasa dengan mengalaminya secara riil atau situasi yang disimulasikan, dan menjadi pelajar yang menjadi mandiri dan otonom (Arends,2008).

Pembelajaran berdasarkan masalah siswa dituntut untuk melakukan pemecahan masalahmasalah yang disajikan dengan cara menggali informasi sebanyakbanyaknya, kemudian menganalisis dan mencari solusi dari permasalahan yang ada. Pembelajaran berdasarkan masalah mengorientasikan siswa kepada masalah, multidisiplin, menuntut kerjasama dalam penelitian dan menghasilkan karya.

Berdasarkan

peneliti sebelumnya, Pohan (2012) di SMPN 5 P.Siantar mendapat nilai pretes 
yang homogen antara kelas eksprimen dengan kelas kontrol. Setelah memberikan perlakuan yang berbeda, kelas eksperimen dengan model pembelajaran berbasis masalah dan kelas kontrol dengan pembelajaran konvensional mengakibatkan hasil belajar di kelas eksperimen mengalami peningkatan yang signifikan. Selain itu, Hasibuan (2011) di SMAN 1 Labuhan Deli, hasil penelitian beliau disimpulkan bahwa ternyata model pembelajaran berbasis masalah lebih baik daripada pembelajaran konvensional.

\section{METODE PENELITIAN}

Penelitian ini dilaksanakan di SMA Negeri 1 Hinai yang beralamat di Jalan Olahraga, Kecamatan Hinai Kabupaten Langkat dan pelaksanaannya dimulai pada tanggal 11 Januari 2014 hingga 05Mei 2014 pada Semester II T.A. 2013/2014.Populasi dalam penelitian ini adalah siswa kelas $\mathrm{X}$ yang terdiri dari empat kelas yaitu dari kelas $\mathrm{X}^{-1}$ sampai $\mathrm{X}^{-}$ 4. Menentukan sampel diambil dengan teknik clusterrandom sampling dan diperoleh kelas eksperimen adalah kelas $\mathrm{X}-1$ dan kelas kontrol adalah kelas X-2 yang masing-masing berjumlah 30 orang.

Penelitian ini melibatkan dua kelas yang diberi perlakuan yang berbeda. Satu kelas dijadikan kelas eksperimen dan kelas lainnya dijadikan kelas kontrol. Untuk mengetahui hasil belajar siswa diberikan perlakuan yang berbeda pada kedua kelas tersebut. Desain penelitian ini dapat dilihat pada Tabel 1.
Tabel1. Two Group Pretes - Posttes Design

\begin{tabular}{|l|c|c|c|}
\hline Kelompok & Pretes & Perlakuan & Postes \\
\hline $\begin{array}{l}\text { Kelas } \\
\text { eksperimen }\end{array}$ & $\mathrm{T}_{1}$ & $\mathrm{X}$ & $\mathrm{T}_{2}$ \\
\hline $\begin{array}{l}\text { Kelas } \\
\text { control }\end{array}$ & $\mathrm{T}_{1}$ & $\mathrm{Y}$ & $\mathrm{T}_{2}$ \\
\hline
\end{tabular}

Keterangan :

T1=Pretes di berikan kepada kelas eksperimen dan kelas kontrol sebelum perlakuan.

T2=Postes di berikan setelah perlakuan pada kelas eksperimen dan kelas kontrol.

$\mathrm{X}=$ Pengajaran dengan menerapkan model pembelajaran berbasis masalah.

$\mathrm{Y}=$ Pengajaran dengan menerapkan model pembelajaran konvensional.

$\mathrm{T} 1$ =T2 (soal pretes sama dengan soal postes).

Penelitimemberikan pretes kepada kelas eksperimen dan kelas kontrol. Instrumen yang digunakan tes kognitif berjumlah 8 soal essai. Tes hasil belajar terlebih dahulu distandarisasi dengan menggunakan uji validitas isi oleh dua orang dosen dan satu guru sesuai dengan pakar ahlinya. Setelah data pretes diperoleh, dilakukan analisis data dengan uji normalitas dengan uji Llilliefors dan uji homogenitas dengan uji kesamaan varians.Setelah itu dilakukan pengujian hipotesis uji $t$ untuk mengetahui kemampuan awal siswa pada kedua kelompok sampel dalam hal ini kemampuan awal kedua sampel tersebut harus sama. Selanjutnya peneliti mengajarkan materi pelajaran dengan menggunakan model pembelajaran berbasis masalah 
pada kelas eksperimen dan pembelajaran konvensional pada kelas kontrol. Untuk mengetahui perbedaan hasil akhirnya maka dilakukan postes menggunakan uji t untuk mengetahui pengaruh perlakuan model pembelajaran berbasis masalah terhadap hasil belajar siswa.

\section{HASIL DAN PEMBAHASAN Hasil Penelitian}

Data yang dideskripsikan pada penelitian ini meliputi data hasil belajar fisika pada materi Listrik Dinamis, yang diberikan perlakuan berbeda yaitu 1) pembelajaran berbasis masalah, 2) pembelajaran dengan menggunakan pembelajaran konvensional. Hasil belajar distribusi frekuensi data pretes siswa kelas eksperimen dan kontrol dapat ditunjukkan dalam Gambar 1.

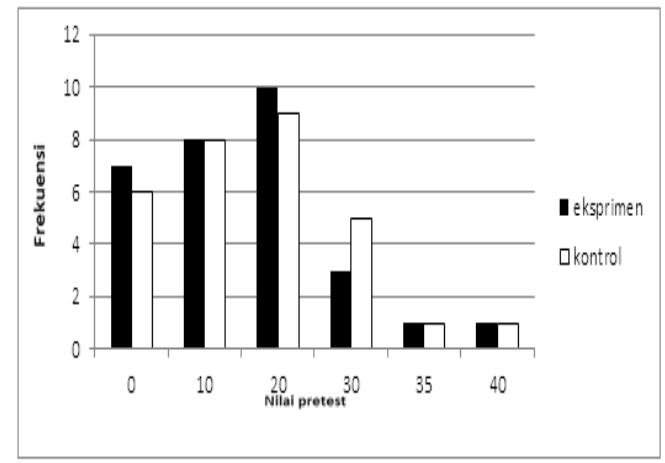

Gambar 1. Diagram Nilai Pretes Diagram

batang

menunjukkan bahwa nilai pretes pada kelas eksperimen dan kelas kontrol memiliki nilai yang sangat rendah namun nilai kelas kontrol sedikit lebih tinggi dibandingkan dengan kelas eksperimen perbandingan rata-rata nilainya adalah 14,83 dan 16,17. Distribusi frekuensi data postest siswa kelas eksperimen dan kontrol dapat divisualisasikan dalam diagram batang hasil pretes siswa kelas eksperimen dan kontrol ditunjukkan pada Gambar 2.

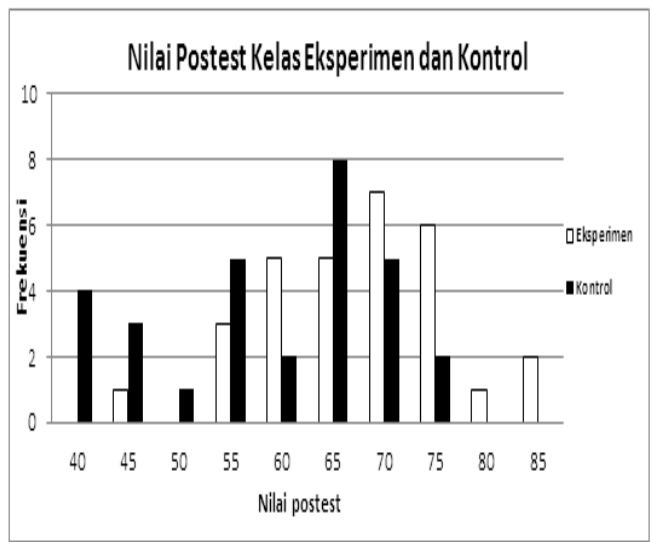

Gambar 2. Diagram Nilai Postes

Gambar 2 menunjukkan bahwa nilai postes kelas eksperimen lebih tinggi dari pada nilai postes kelas kontrol perbandingan ratarata nilainya adalah 67,5 dan 58,67 . Terdapat peningkatan hasil belajar yang diperoleh pada kedua kelas tersebut walaupun tidak begitu besar mencapai ketuntasan minimal. Dengan demikian hasil belajar kelas eksperimen lebih baik dibandingkan dengan hasil belajar kelas kontrol.

Selain dari nilai pretes dan postest hasil belajar juga dapat dilihat dari penilaian afektif dan psikomotorik. Penilaian afektif dilakukan oleh observer selama kegiatan belajar mengajar berlangsung oleh peneliti yang telah dilengkapi lembar penilaian afektif. Adapun aspek yang dinilai adalah : peduli, bekerja sama, berpikir kreatif dan memberi tanggapan. Aspek-aspek tersebut diberi skor 1 sampai 3 dengan pedoman pada lembar observasi siswa. Sedangkan aspek yang dinilai untuk psikomotoriknya adalah menggunakan alat ukur, merangkaian percobaan, membaca hasil percobaan, mengkalibrasi hasil 
percobaan. Aspek-aspek tersebut juga diberi skor 1 sampai 3 dengan pedoman pada lembar observasi siswa. Adapun hasil perkembangan dari afektif dan psikomotorik dikelas dapat ditunjukkan Gambar 3 dan Gambar 4.

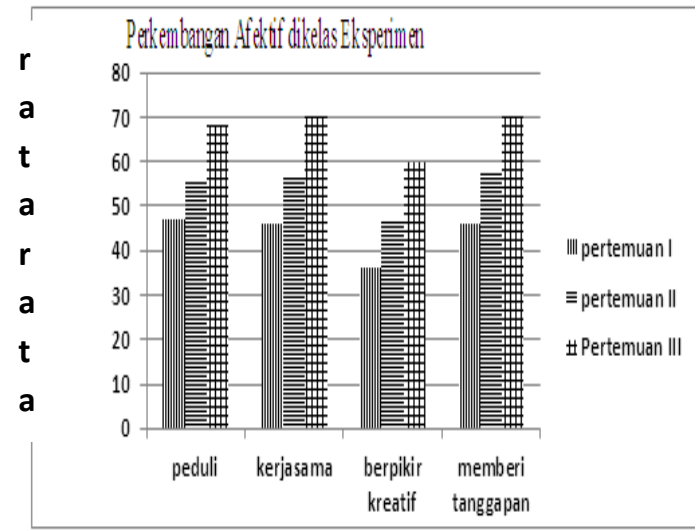

Gambar 3. Diagram Afektif

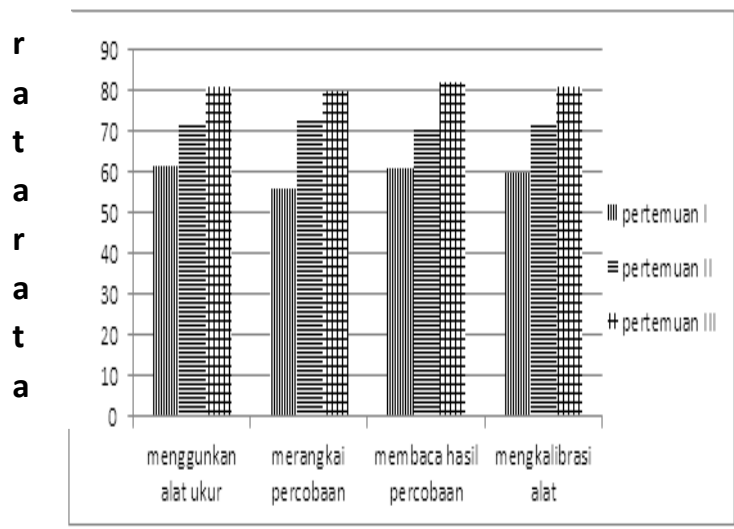

Gambar 4. Diagram Psikomotorik

Dilihat dari hasil belajar afektif maupun psikomotorik terjadi peningkatan hasil belajar dalam setiap pertemuannya, hal ini disebabkan semakin sering model pembelajaran berbasis masalah ini diterapkan, maka siswa pun akan semakin terbiasa dengan model pembelajaran tersebut dan lebih memahami cara pembelajaran berbasis masalah itu, sehingga mampu meningkatkan sikap psikomotorik maupun afektif siswa. Sesuai dengan apa yang diakatan
Arends (2009), "Model PBL ini tidak rumit dan mudah untuk menangkap ide-ide dasar yang terkait dengan model ini. Akan tetapi, pelaksanaan efektif model ini lebih sulit. Sehingga, model ini membutuhkan banyak latihan dan mengharuskan untuk mengambil keputusankeputusan tertentu selama perencanaan dan pelaksanaannya"

\section{Pembahasan}

Kelas eksprimen yang diajar dengan menggunakan model pembelajaran berbasis masalah terjadi peningkatan hasil belajar, dimana nilai rata-rata pretestnya 14,83 sedangkan nilai rata-rata postest adalah 67,5. Peningkatan hasil belajar siswa dikelas eksperimen ini dikarenakan pada saat proses belajar mengajar dengan menggunakan model pembelajaran berbasis masalah menuntut siswa untuk bekerja sama dalam memecahkan masalah yang berkaitan dalam kehidupan seharihari dan menemukan sendiri informasi yang berkaitan dengan masalah. Sesuai dengan teori belajar konstruktivisme menyatakan bahwa siswa harus menemukan sendiri informasi yang kompleks,mengecek informasi baru dengan aturan-aturan lama dan merevisinya apabila aturan-aturan itu tidak sesuai lagi. Bagi siswa, agar benar-benar memahami dan dapat menerapkan pengetahuan, mereka harus memecahkan masalah, menemukan segala sesuatu untuk dirinya,berusaha denga susah payah dengan ide-ide. Maka dari itu, dalam proses pembelajaran siswa merasa sangat senang dengan adanya pembelajaran dengan mengunakan 
model pembelajaran berbasis masalahkarena siswa bisa merasakan sendiri peristiwa yang berkaitan dengan kehidupan seharihari, yang sedang dipelajari.

Kelas kontrol yang diajar dengan menggunakan pembelajaran konvensional terjadi peningkatan hasil belajar, dimana nilai rata-rata pretestnya 16,17sedangkan nilai rata-rata postest adalah 58,67. Besarnya peningkatan hasil belajar di kelas kontrol ini masih lebih rendah jika dibandingkan dengan kelas eksprimen yang menggunakan model pembelajaran berbasis masalah.

Hal ini disebabkan, pada pembelajaran konvensional ini menyampaikan informasi dengan lisan kepada sejumlah siswa. Kegiatan ini berpusat pada penceramah dan komunikasi yang searah. Pada model pembelajaran konvensional, siswa belajar lebih banyak mendengarkan penjelasan di depan kelas dan melaksanakan tugas jika diberikan latihan soalsoal kepada siswa. Sistem konvensional pengajaran yang dilakukan dalam proses belajar mengajar yaitu dengan menggunakan metode ceramah, tanya jawab dan demonstrasi,sehingga siswa merasa bosan, pasif dan mudah cepat lupa.

Hasil penelitian menunjukkan bahwa rata-rata nilai postes di kelas eksprimen (67,5) lebih tinggi daripada rata-rata nilai postest kelas kontrol (58,67). Sehingga dapat disimpulkan bahwa hasil belajar fisika menggunakan model pembelajaran berbasis masalah lebih baik daripada hasil belajar menggunakan konvensional. Hasil ini memberikan informasi bahwa ada efek yang positif model pembelajaran berbasis masalah dalam meningkatkan hasil belajar fisika siswa.

Adapun beberapa kelebihan dari model pembelajaran berbasis masalah adalah : 1. Meningkatkan motivasi belajar karena siswa dilibatkan secara aktif dalam proses pembelajaran, 2. Siswa di latih untuk mengkaitkan permasalahan yang dipelajari dengan kehidupan sehari-hari sehingga siswa dituntut untuk belajar menemukan, 3. Siswa lebih dalam berpikir tingkat tinggi, seperti menganalisis, memecahkan masalah yang terjadi dalam kehidupan sehari-hari, menemukan, mevaluasi, bekerja sama, menunjukkan komunikasi yang baik antar sesama teman. Selain itu, model pembelajaran berbasis masalah dapat memberikan kesempatan pada siswa bereksplorasi mengumpulkan dan menganalisis data untuk memecahkan masalah, sehingga siswa mampu untuk berpikir kritis, analitis, sistematis, dan logis dalam menemukan alternatif pemecahan masalah. Siswa dalam hal ini aktif dan antusias untuk bekerja sama dengan teman satu kelompok dalam menyelesaikan masalah yang telah diberikan oleh peneliti. Siswa juga tertarik dan aktif saat berdiskusi dan mengeluarkan pendapat yang berbeda saat diadakan diskusi antar kelompok.

Tahap orientasi siswa pada masalah (pertama), peneliti memotivasi siswa dengan memberikan tujuan pembelajaran yang akan dicapai oleh siswa dan pada tahap ini peneliti memberikan 
masalah kepada siswa dengan menunjukkan dua buah rangkaian sederhana yang berbeda. Pada tahap mengorganisasi siswa untuk belajar (kedua), peneliti memberikan materi pelajaran yang dipelajari kemudian membentuk kelompok-kelompok belajar dan melakukan percobaan (eksperimen). Pada tahap penyelidikan individual maupun kelompok (ketiga), peneliti membimbing setiap siswa untuk mengumpulkan informasi untuk memecahkan masalah, dan melakukan percobaan (eksperimen) sekali lagi. Pada tahap mengembangkan dan mempresentasikan artefak dan exhibit (keempat), peneliti membantu setiap kelompok menyelesaikan dan menjawab semua permasalahan yang ada, serta mempersentasikan hasil diskusi kelompok yang sudah disiapkan, kemudian kelompok yang lain diberikan kesempatan memberikan pendapat atau masukan. Pada tahap menganalisis dan mengevaluasi proses mengatasi masalah (kelima), peneliti membantu siswa dalam mengkaji ulang pemecahan masalah sesuai dengan tujuan pembelajaran dan memberikan penguatan pada pemecahan masalah tersebut dan pada tahap ini peneliti membuat tes evaluasi untuk mengetahui pemahaman siswa.

Hasil penelitian ini sejalan dengan penelitian terdahulu seperti yang di teliti oleh Kharida, dkk (2009), menyatakan dalam hasil penelitiannya terjadi peningkatan rata-rata hasil belajar kognitif siswa yang diajar dengan model pembelajaran berbasis masalah.
Yasa (2007) menunjukkan kompetensi dasar fisika siswa dapat ditingkatkan dengan menggunakan strategi berbasis masalah. Baskoro, dkk (2009) dengan model pembelajaran berbasis masalah dapat meningkatkan aktivitas listening, oral, emotional, visual, writing, motor, dan mental. Orhan (2010) showthatproblem-based active learning model had positively affected students' academic achievement and their attitudes towards the science course. Tika (2012),model PBL dapat meningkatkan secara signifikan pemahaman konsep fisika siswa.

Model pembelajaran berbasis masalah telah membuat hasil belajar yang lebih baik dibandingkan dengan pembelajaran konvensional,tetapi ada beberapa hal kendala-kendala dalam melakukan penelitian, yaitu 1) Peneliti belum maksimal dalam mengelola waktu sehingga semua sintaks kurang efektif saat pelaksanaan proses pembelajaran. 2) Siswa masih lebih banyak karena model ini belum pernah diterapkan disekolah tersebut

\section{Saran}

Bagi guru, hendaknya menguasai semua sintaks dalam Pembelajaran Berbasis Masalah dan mengatur waktu untuk melaksanakan semua sintaks tersebut dengan tepat waktu dan siswa tersebut tidak merasa kesulitan di dalam mengikuti semua sintaks tersebut.

Bagi peneliti selanjutnya hendaknya melakukan simulasi sebelum mencobakan model ini terhadap siswa agar siswa lebih memahami dan terlatih dengan cara 
kerja model pembelajaran ini ketika melakukan penelitian,sehingga model pembelajaran berbasis masalah ini bisa diselesaikan tepat waktu.

\section{DAFTAR PUSTAKA}

Akınoğlu, Orhan and Ruhan Özkardeş

Tandoğan,(2007).The Effects of Problem Based Active Learning in Science Education on Students' Academic Achievement, Attitude and Concept Learning, Marmara Üniversitesi, Eurasia Journal of Mathematics, Eurasia Journal of Mathematics Science \& Technology Education 3.7181

Arends,RichardI,(2009).Learning to teach,Penerbit Pustaka Pelajar,Yogyakarta

Arikunto.S,(2000),Manajemen

Penelitian,Rineka

Cipta,Jakarta

Fakultas Matematika dan Ilmu Pengetahuan Alam universitas Negeri Medan, (2012), Buku Pedoman Penulisan Skripsi Mahasiswa dan Standar Operasional (SOP) Kepembimbingan Skripsi Program Studi Pendidikan, FMIPA Unimed, Medan.

Hasbullah,(1991).Dasar-dasar IImu Pendidikan,Erlangga,Jakarta

Kharida,L.A,dkk,(2009).Penerapan Model Pembelajaran Berbasis Masalah Untuk Peningkatan Hasil Belajar Siswa Pada Pokok Bahasan Elastisitas
Bahan,Jurnal Pendidikan Fisika Indonesia 5:83-89

Pohan,Ahmad

Fauzi,(2012).Pengaruh

Model Pembelajaran

Berbasis Masalah

Terhadap Hasil Belajar Siswa

Pada Materi Pokok Listrik Dinamis Kelas IX SMP N 5 Pematangsiantar T.P 2012/2013, Skripsi, Jurusan Fisika FMIPA, UNIMED, Medan.

Tika, I Ketut,(2008).Penerapan Problem Based Learning Berorientasi Penilaian Kinerja Dalam Pembelajaran Fisika Untuk meningkatkan Kompetensi Kerja Ilmiah Siswa, Jurnal Pendidikan dan Pengajaran UNDIKSHA 3:648-700

Yasa,Putu,(2007).Strategi

pembelajaran berbasis masalah untuk meningkatkan kompetensi dasar fisika siswa kelas viii SMP N 2 Singaraja,Jurnal Pendidikan dan Pengajaran UNDIKSHA 3:622-637 